\title{
Powerful Patens in the Anglo-Saxon Medical Tradition and Exeter Book Riddle 48
}

\author{
Megan Cavell ${ }^{1}$
}

Published online: 24 June 2016

(C) The Author(s) 2016. This article is published with open access at Springerlink.com

\begin{abstract}
This article discusses Exeter Book Riddle 48 in light of its proposed solutions. While commonly solved as either "chalice" or "paten," I argue that the riddle points toward the latter solution (OE husel-disc). This riddle is usually read in relation to its counterpart, Riddle 59, which scholarly consensus solves as "chalice" (OE calic or husel-fat). However, Riddle 48 should be analysed in its own right, especially given evidence from the medical tradition that prescribes writing on patens and performing psalms and other prayers over them in order to cure sickness. It is to this practice and to the psalms that Riddle 48 gestures in its use of the term galdorcwide (incantation), as well as the direct quotation that appeals to God to heal the speaker.
\end{abstract}

Keywords Old English · Riddle 48 · Solution · Husel-disc · Paten · Medicine

Like many of the riddles in the tenth-century Exeter Book, Riddle $48^{1}$ has had its fair share of proposed solutions. Although it is most commonly interpreted as a sacramental vessel-either a chalice or paten-it has also been read as a book or finger ring, and analysed briefly in relation to coins, bells and brooches. ${ }^{2}$ While all of these readings acknowledge the high-status nature of the object depicted in

\footnotetext{
1 According to Krapp and Dobbie's numbering system.

2 This list of potential solutions is addressed alongside "finger ring" in Okasha (1993). For the "book" interpretation, see Anderson (1983).

Megan Cavell

megan.cavell@durham.ac.uk

1 Department of English Studies, Durham University, Elvet Riverside, New Elvet, Durham DH1 3JT, UK
} 
Riddle 48, this article argues that evidence which supports solving the riddle as a husel-disc (paten) can be found in the Anglo-Saxon medical tradition.

Riddle 48 begins with a third-person witness describing a paradoxically silent speaker who is quoted directly halfway through the poem ${ }^{3}$ :

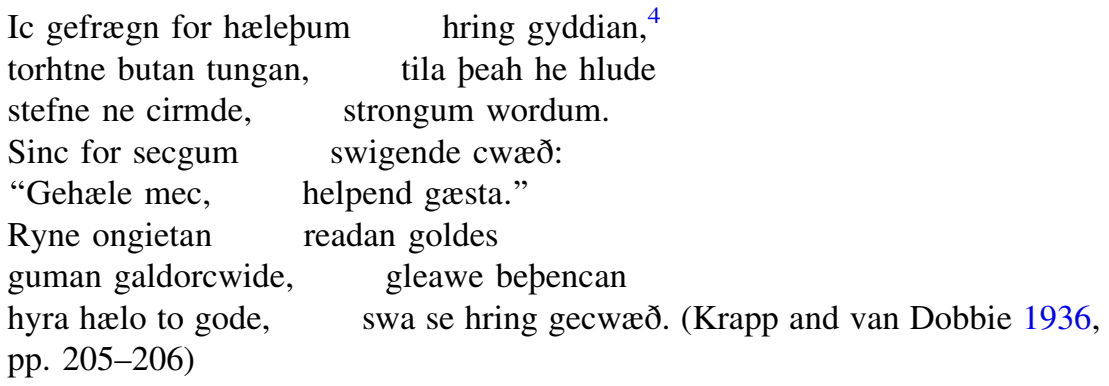

(I heard a ring sing before men, bright, without a tongue, rightly with strong words, although it did not yell in a loud voice. The treasure, silent before men, spoke: "Heal/Save me, helper of souls." May men interpret the mystery of the red gold, the incantation, may they wisely entrust their health/salvation to God, as the ring said.)

Given the direct quotation's reference to healing/saving and helping souls, as well as the final lines' clear evocation of a link between the riddle object, salvation and God, scholars have good reason to assume the object belongs to a religious, possibly even liturgical, context. Likewise, line 6b's reference to read gold (red gold) points to a crafted item of the highest quality and status. ${ }^{5}$

The distinctiveness of the clues that depict a ring-shaped, tongue-less, golden treasure conveying a message makes it possible to achieve at least partial scholarly consensus. Thus the most recent editors of the riddles, Williamson (1977, pp. 46-47), Pinsker and Ziegler (1985, pp. 263-264) and Muir (2000, vol. i, p. 662), narrow the solution down to either "chalice" or "paten." 6

Few alternatives have been discussed in depth, apart from "book" and "finger ring." James Anderson suggests the first solution in his discussion of Riddles 47 and 48. He argues that because the two riddles are not as clearly separated from one

\footnotetext{
3 For more on the silent speaker paradox, see Hayes (2008); Nelson (1978, pp. 611-612); Nelson (1989, pp. 129-131); and Salvador-Bello (2015, p. 365). Note that direct quotations, though rare in the riddles, are not unheard of; see also Riddle 33 and Riddle 38, in Krapp and van Dobbie (1936).

4 Note that line 1b reads hringende an in the manuscript, which Krapp and Dobbie emend to hring endean. I have followed Williamson (1977, pp. 97 and 288-299), because his emendation makes the best linguistic, metrical and contextual sense of the line. See also Muir (2000, vol. i, p. 320 and vol. ii, pp. 647-648).

5 Two glosses especially speak to the quality of read gold: the phrase is linked to aurum obrizum (fine gold) in one glossary, and read goldlafer is linked to auri obriza lammina (fine gold-leaf) in a second. See Kindschi (1955, gloss 570) and Napier (1900, gloss 1070). For more on the colour denoted by this phrase, see Anderson (2000).

${ }^{6}$ See also Andy Orchard's forthcoming edition of the Anglo-Saxon riddle tradition for the Dumbarton Oaks Medieval Library, and the list of Old English solutions in Niles (2006, p. 143), both of which include husel-disc (paten) as the solution to this riddle.
} 
another on the manuscript page as other riddles in the Exeter Book-although the opening Ic of Riddle 48 has an elongated small capital "I" and follows a raised point - the poems represent a spliced text (1983, pp. 57-63). Reading the hring (ring) of Riddle 48 as a "ringing," Anderson suggests that the two poems together depict a book of offices linked to the sounding of bells at particular hours (p. 61). However, although he similarly reads the two riddles together (and separately), Martin Foys notes that the imagery of the bookworm's unthinking consumption in Riddle 47 works well with a reading of Riddle 48 as a sacramental vessel (forthcoming). I am inclined to agree.

The second alternative is "finger ring," which Elisabeth Okasha prefers as the solution to both Riddle 48 and Riddle 59 (1993, 2003, pp. 36-37). Okasha addresses in turn the following options, on the grounds that they are circular, metal objects, which may bear a message, and can be passed from hand to hand (as in Riddle 59): sacramental vessel, coin, bell, brooch and finger ring (1993). She presents both archaeological and written evidence, and in doing so focuses on the golden and inscribed nature of Riddle 48's object, as well as on the number or lack of surviving examples of each object from the material record. Okasha finds that the evidence for Anglo-Saxon sacramental vessels that are made of gold and inscribed is "circumstantial," making this solution "less than compelling" (1993, p. 63). I will return to this evidence below. She rejects "coin" on the grounds that silver coins are more common than gold, and because religious inscriptions are rare on Anglo-Saxon coins (1993, pp. 64-65). Likewise, Okasha notes that there are only a few references to small bells in Anglo-Saxon texts, and comparative texts indicate that copper and tin were more common in bell-making than gold; this solution is possible, but circumstantial (1993, p. 65). A similar line is taken when it comes to brooches; even though examples that are circular, gold or inscribed exist from Anglo-Saxon England, none of the surviving items unites all three features (p. 66). When it comes to finger rings, however, Okasha notes that at least ten surviving examples (at the time of publication) are of gold and bear an inscription, and in several cases this inscription has Christian connotations (though nothing close to the direct quotation of Riddle 48) (1993, pp. 66-67). She concludes: “This proposal has the attractions of both fitting all the clues provided by the riddler and of being based on the actual evidence of existing Anglo-Saxon artefacts" (1993, p. 67).

While it is tempting to link Old English riddles to material culture, as Okasha has done for Riddle 48 and Riddle 59, Jennifer Neville argues that the playful and misleading nature of the riddles "makes them a precarious source of insight into material culture, and they need to be treated with more caution than is usually accorded them" (2013, p. 122). The same could perhaps be said of the inverse relationship. Since preservation is often down to chance, those items that do survive in the material record should not be taken as the final word on which objects were common or revered enough to make their way into the riddles.

Indeed, one of the biggest problems with Okasha's argument is that survival rates do not reflect the number of objects in use at the time [as she herself points out in relation to sacramental vessels $(1993$, p. 63)]. There are also issues with the solution "finger ring" that are specific to Riddle 48, such as the fact that hring (ring) appears in the opening and closing lines of the poem. The presence of the solution at the 
beginning of the riddle is not an insurmountable problem, since Riddle 47 (bookworm) — which directly precedes Riddle 48-opens with a direct reference to its solution in the form of mоððe (moth). Given that there is no end punctuation immediately following Riddle 47, as noted above, one could argue that these poems are thematically linked (cf. Salvador-Bello 2015, p. 360; Anderson 1983, p. 59; and Foys forthcoming). If taken as a sacramental vessel, then Riddle 48's associations with food/drink and religious worship could be mirrored in Riddle 47's depiction of an insect thoughtlessly devouring holy words.

A further issue with which Okasha does not engage is the differing uses of finger rings and sacramental vessels. Even if survival rates could give us definitive proof of an object's prevalence in the period, it would be natural to expect far fewer sacramental vessels than finger rings. Finger rings are personal objects, while church paraphernalia is shared-being both displayed to and used by a great many people during religious rituals. This different context means that even if the composer of Riddle 48 were unlikely to have had personal access to sacramental vessels (compared to finger rings), s/he would likely have had a familiarity with them. Certainly we can assume that the scribe preserving the riddle in its current form would be familiar with the paraphernalia of religious worship, given that the Exeter Book is a high-status manuscript that survives in a cathedral library.

Furthermore, as Okasha and others have noted, specific written evidence for the use of sacramental vessels made of gold exists in both early and late Anglo-Saxon texts. ${ }^{7}$ For example, Ælfric's First Old English Letter for Wulfstan states: Beo his calic geworht of ecum antimbre, gylden oppe sylfren, glasen oppe tinen. Ne beo he na hyrnen ne huru treowen (Fehr 1914, p. 126, cols. 161-162) (Let his [the masspriest's] chalice be made of enduring material, of gold or silver, of glass or of tin. Let it not be of horn nor indeed of wood). Williamson argues that Riddle 48's reference to gold is evidence that "chalice" (OE calic or husel-fat) may be the more likely solution, given that the ecclesiastical laws associate gold with chalices rather than patens (1977, p. 287). Of course, there is a logical reason for greater interest in the material of the chalice than the paten; a more enduring material than wood or horn is required in order to prevent the sacramental vessels from absorbing the consecrated elements. This is obviously a greater concern where liquid is involved.

Such logic does not, however, explain the earlier example from Aldhelm's Carmina Ecclesiastica, which specifies a chalice of gold and a paten of silver:

Aureus atque calix gemmis fulgescit opertus,

Ut caelum rutilat stellis ardentibus aptum,

Ac lata argento constat fabricata patena:

Quae divina gerunt nostrae medicamina vitae. (Ehwald 1919, p. 18, Song 3, 1. 72-75)

(and the gold chalice covered with gems glitters, just as heaven set with burning stars glows, and the broad paten fashioned from silver matches: those which carry the divine remedies of our life.)

\footnotetext{
${ }^{7}$ See also the mid/late-eleventh-century references to chalices and patens in the Anglo-Saxon Chronicle and two Ely inventories listed in Okasha (1993, p. 63).
} 
While this example gives evidence for a potential differentiation between chalices and patens by material, Ælfric's Letter to Wulfsige makes an explicit link between both objects: Beo his calic eac of clanum antimbre geworht, unforrotigendlic and eall-swa se disc (Fehr 1914, p. 14, col. 58) (Let his chalice also be made of pure material, incorruptible, and likewise the dish). This example suggests that the paten should be made of the same material Ælfric listed of the chalice in his First Old English Letter for Wulfstan. In fact, one manuscript containing the Letter to Wulfsige-Oxford, Bodleian Library, Junius 121-elaborates upon what constitutes an incorruptible material by adding gylden oððe seolfren oððe tinen oð glasen (of gold or of silver or of tin or of glass) before and ealswa se disc (and likewise the dish) (Fehr 1914, p. 14, col. 58). Thus, it is perhaps unwise to rule out the solution "paten" based on an absence of evidence.

This absence of evidence is also something that Okasha relies on when noting that no inscribed sacramental vessels occur in the Anglo-Saxon archaeological or written records (1993, p. 63). In fact, scholarship in general takes for granted that the message is engraved into the gold of the object depicted in Riddle 48. This assumption may stem from references to the wounds of the similar object in Riddle 59, whose solution appears to be "chalice." 8 This riddle object is said to silently speak and make known the name of its lord for those who interpret it correctly:

$\quad$ gif pæs æpelan
goldes tacen $\quad$ ongietan cupe
ond dryhtnes dolg, don swa pæs beages
benne cwædon. (Krapp and van Dobbie 1936, pp. 209-210, 11. 9b-12)

(if one could understand the symbol of the noble gold and the injuries of the lord, do as the wounds of the ring said.)

Riddle 59 makes further reference to wounds when it challenges would-be solvers in the final lines:

hu ðæs wrætlican
hringes to hælepum,
wylted ond wended
p. $210,11.15 \mathrm{~b}-18)$

Ræde, se pe wille, wunda cwæden pa he in healle wæs wloncra folmum. (Krapp and van Dobbie 1936,

(Let he who wishes determine how the wounds of the wondrous ring spoke to warriors, when it was in the hall turned and moved by the hands of the proud ones.)

Scholars have interpreted these injuries-which are clearly linked to Christ's wounds-as an inscription (see Hayes 2008, p. 133; Okasha 1993, p. 62; Orchard 2016, pp. 79-80; Pinsker and Ziegler 1985, p. 281; Salvador-Bello 2015, p. 377;

\footnotetext{
8 All recent editions of the riddles solve Riddle 59 as "chalice" (or an inscription on a chalice). See Williamson (1977, pp. 313); Pinsker and Ziegler (1985, pp. 281-282); and Muir (2000, vol. i, p. 663). This is also the only option given in Krapp and van Dobbie (1936).
} 
Williamson 1977, pp. 313-314). This reading is a valid one, but the riddle's wounds may also simply refer to the process of manufacturing and decorating a metal object, which would involve a great deal of turning, striking, binding, and incising. Indeed, Dieter Bitterli has discussed other religious objects' associations with painful manufacturing in the light of Old English literature's fascination with martyrdom (2009, pp. 170-190). If the chalice that results from such manufacturing processes is imagined to bear a cross or other symbolic imagery, it could still be described as speaking to its audience about the crucifixion and salvation.

Even if the wounds of Riddle 59 do relate to engraving, Riddle 48 does not itself allude to an inscription that is an inseparable component of the sacramental vessel being described. This is particularly significant because writing on patens is mentioned several times in the medical tradition where the practice is invoked in relation to rituals for curing the sick. One such example can be found in Bald's Leechbook I:

Pis mon sceal writan on husl disce 1 on pone drenc mid halig wætere pwean 1 singan on. [...] In principio erat verbum et verbum erat aput deum et deus erat verbum. Hoc erat In principio aput deum omnia per ipsum facta sunt. Pweah ponne pæt gewrit mid halig wætre of pam disce on pone drenc. sing. ponne credo 1 pater noster 1 pis leop. beati Inmaculati pone sealm mid ad dominum pam. XII. gebed sealmum. Adiuro vos frigores et febres. per deum patrem omnipotentem et per euis filium / Jesum Cristum per ascensum et discensum Salvatoris nostri ut recedatis de hoc famulo dei. et de corpusculo eius quam dominus noster inluminare Instituit. Vincit vos leo de tribu iuda radix david. Vincit vos qui vinci non potest. Cristus natus. Cristus passus. Cristus venturus. aius. aius. aius. Sanctus. Sanctus. Sanctus. In die Salutiferis incedens gressibus urbes. oppida rura vicos castra castella peragrans. Omnia depulsis sanabat corpora morbis. 1 priwa ponne onsupe pæs wæteres swelces gehwæper para manna. ${ }^{9}$ (British Library Digitised Manuscripts, Royal MS 12 D XVII, fols. $51 \mathrm{r}-51 \mathrm{v}$, col. 62)

(One must write this on a paten and wash it with holy water into the drink, and sing over it. "In the beginning was the Word, and the Word was with God, and the Word was God. The same was in the beginning with God. All things were made by him" "11 [John 1.1-3]. Then with the holy water wash the writing off the dish into the drink, then sing the Creed and the Lord's Prayer and this song, "Blessed are the undefiled" [Psalm 118], the psalm with "to the Lord" [Psalm 119] and the twelve prayer psalms. I adjure you, chills and fevers, through God, the all-powerful father, and through his son, Jesus Christ, through the ascension and descent of our Saviour, that you recede from this servant of God, and from his body, as our Lord prepares to illuminate. The lion from the tribe of Judah, the root of David, conquers you. He, who is unable to be conquered, conquers you. Christ was born. Christ suffered. Christ will

\footnotetext{
9 The use of the paten is also mentioned in the Book's contents list on fol. 5r.

10 Alpha and omega surrounded by seventeen crosses appear alongside the next two manuscript lines.

11 All quoted Vulgate translations refer to the Holy Bible Douay-Rheims Version.
} 
come. Holy [Greek]. Holy. Holy. Holy [Latin]. Holy. Holy. ${ }^{12}$ From there $^{13}$ proceeding with healing steps, passing through cities, towns, farms, villages, forts, strongholds, he healed all the bodies, having expelled their ailments [Sedulius, Carmen Paschale, Bk 3, 11. 23-5]. And let each of the two people then sip three times of this water.)

The instructions clearly refer to writing on a paten, washing it with holy water, and praying over the mixture. The writing is presumably to be undertaken with a material that will not damage the object. Alternately, Karen Jolly suggests the writing may be symbolic, such as when a priest makes the sign of the cross with his finger (1996, p. 120).

A similar remedy occurs in the Lacnunga:

Pis is se halga drænc wið ælf sidene 1 wið eallum feondes costungum writ on husl disce. In principio erat verbum usque non conprehenderunt et plura. et circumibat Jesus totam galileam docens usque et secuti sunt eum / turbe multe. Deus in nomine tuo usque in finem. Deus misereatur nobis usque in finem. Domine deus in adiutorium usque in finem. Nim cristallan 1 disman 1 sidewaran $\rceil$ cassuc $\rceil$ finol $\rceil$ nim sester fulne gehalgodes wines $\rceil$ hat unmælne mon gefeccean swigende ongean streame healfne sester yrnendes wæteres nim ponne 7 lege ða wyrta ealle in pæt wæter 7 pweah pæt gewrit of ðan husl disce pærin swiðe clæne geot ponne pæt gehalgade win ufon on ðæt oper ber pon to ciricean læt singan mæssan ofer. ane / omnibus. oðre Contra tribulatione priddan sanctam marian Sing ðas gebedsealmas. Miserere mei deus. Deus in nomine tuo Deus misereatur nobis. Domine deus Inclina domine 1 credo 1 Gloria in excelsis deo. 1 letanias. Pater noster 7 bletsa georne in ælmihtiges drihtnes naman $\rceil$ cweð in nomine patris et filii. et spiritus sancti sit benedictum bruc syppan. (British Library Digitised Manuscripts, Harley MS 585, fols. 137r-138r)

(This is the holy drink against elf affliction and against all temptations of the devil: write on a paten, "In the beginning was the Word" up to "did not comprehend it" [John 1.1-5], moreover "And Jesus went about all Galilee, teaching" up to "and much people followed him" [Matthew 4.23-5] [and] "O God, by thy name" up to the end [Psalm 53], [and] "May God have mercy on us" up to the end [Psalm 66], [and] "Lord God, [come] to my assistance" up to the end [Psalm 69]. Take cristalla [a plant] and musk and zedoary and sedge and fennel, and take a full pitcher of consecrated wine, and command an unblemished person to fetch silently against the current half a pitcher of running water; then take and lay all the plants in that water and wash off the writing inside the paten very cleanly; then pour the consecrated wine from above onto the other [liquid]; then carry it to the church; have masses sung over it, firstly "To all [the saints]" [Psalm 149], secondly "Against tribulation," thirdly "Holy Mary". Sing these precatory psalms: "Have mercy

\footnotetext{
12 Crosses appear above each of the three instances of Christus, aius and Sanctus in the manuscript.

13 The Anglo-Saxon medical text reads in die, while the quotation from Sedulius reads inde (see Springer 2013, p. 78).
} 
on me, O God" [Psalm 50], "O God, by thy name" [Psalm 53], "May God have mercy on us" [Psalm 66], "Lord God" [Psalm 88?], "Incline, O Lord" [Psalm 85], and the Creed and "Glory to God in the highest" [Luke 2.14], and litanies, [and] the Lord's Prayer; and eagerly bless [it] in the name of the almighty Lord, and say "In the name of the Father, and of the Son, and of the Holy Spirit let it be blessed"; then use it.)

Again, the method involves writing religious texts upon the paten and washing them off, in this case swiðe claene (very cleanly), which implies that the writing is material rather than symbolic. Another list of liturgical readings are then prescribed before the mixture can be used. The vagueness of the verb brucan makes it unclear how the mixture is to be employed, but the Dictionary of Old English's sense 1.a.i. perhaps fits the context best: "to partake of food or drink" (Healey et al. 2007; hereafter DOE). Like the remedy in Bald's Leechbook I, we can assume this mixture is to be drunk.

The use of patens in the medical tradition is, of course, directly relevant to Riddle 48, given the quotation in line 5: Gehole mec, helpend gasta (Heal/Save me, helper of souls). Williamson reads this line as a reference to the liturgy, and specifically to the Lord's Prayer's final petition, libera nos a malo (Matthew 6.13; Fischer et al. 1994, p. 1533) (deliver us from evil), after which the bread is broken (1977, p. 288). Pinsker and Ziegler (1985, p. 263), the DOE (s.v. galdorcwide) and Orchard (2016, p. 79), on the other hand, see a reference to the beginning of Psalm 11.2: Salvum me fac, Domine (Fischer et al. 1994, p. 780) (Save me, O Lord). This reading is especially intriguing, given that Psalm 11.2 from the Old English Paris Psalter employs the same verb as Riddle 48 when it opens with: Gehol me, Drihten (Heal/ Save me, Lord) (O'Neill 2001, p. 110). Of course, the riddles revel in misdirection and multi-layered interpretations, which makes it possible that line 5 is also a reference to the use of this sacramental vessel in practical medicine. For the remedies outlined above to be performed, the participation of a priest was necessary (since masses were to be said over the remedy); the remedies were not, therefore, taking place behind closed doors, and in fact they were highly liturgical in nature (Jolly 1996, p. 142). Moreover, the phrase salvum me fac is not unique to the psalm that Pinsker and Ziegler, the DOE and Orchard argue Riddle 48 is quoting. In fact, the phrase occurs in one of the psalms (Deus in nomine tuo) that the Lacnunga charm calls for twice. Psalm 53.3 reads: Deus in nomine tuo salvum me fac et in virtute tua iudica me (Fischer et al. 1994, p. 834) (Save me, O God, by thy name, and judge me in thy strength). It is, therefore, possible that Riddle 48 points to the use of both the paten and the psalms in practical medicine.

There is another clue in Riddle 48 that suggests a connection with the medical tradition: line 7 includes the hapax legomenon compound, galdorcwide (incantation). The $D O E$ - assuming perhaps that magic does not fit within the religious context of the riddle-translates this term as "powerful saying (ref. to the inscription on the paten or chalice, viz. the prayer of 1.5 of the Riddle [= Ps 11:2])." However, the majority of occurrences of galdor and its compounds hold clear associations with charms, spells and incantations spoken in both the contexts of magic and medicine (cf. DOE), and there is no reason to believe that this particular 
compound differs. The riddle highlights an act of public performance through this term and line 1a and 4a's emphasis on speaking for halepum/secgum (before men) (Orchard 2016, p. 79), which fits well within the context of performing a cure like the ones outlined above. In a world where illnesses are combatted through a treatment that involves speaking blessings over a paten, it makes sense to find incantations within a riddle about the very same sacramental vessel.

Given the above evidence for writing on patens during the preparation of medical remedies, and given the presence of a term with clear medical and magical associations in Riddle 48, I would argue that the solution the poem prompts is huseldisc. This is not a new solution, but one that has travelled with Riddle 48 from the beginning of its scholarly treatment. Indeed, recent discussions of the riddles have pointed out the merits of reading Riddle 48 and Riddle 59 as a pair that indicate husel-disc (paten) and husel-fat (chalice), respectively (Niles 2006, p. 112). ${ }^{14}$ However, studies of Riddle 48 have until now relied too heavily on comparing it with its riddling counterpart and not heavily enough on the fascinating ties the poem shares with the Anglo-Saxon medical tradition. The above analysis of the medical function of inscribed patens, as well as the clear links between these medical texts' use of psalms and Riddle 48's direct quotation, point to the riddle's wider significance. This is a poem that engages with contemporary practices for which we have good evidence, making the solution more secure and providing us with a link between the riddling and medical traditions. Finally, Riddle 48 reminds us that sacred objects could be used outside of a liturgical context, and underlines how closely both riddling and medicine are associated with highly educated Christian practices.

Acknowledgments I am grateful to the European Union COFUND/Durham Junior Research Fellowship scheme for funding the research and writing of this article. I would also like to thank Helen Foxhall Forbes for her comments on an earlier draft of this article, and Andy Orchard for sharing his notes about Riddle 48 (numbered Riddle 46 in his forthcoming edition).

Open Access This article is distributed under the terms of the Creative Commons Attribution 4.0 International License (http://creativecommons.org/licenses/by/4.0/), which permits unrestricted use, distribution, and reproduction in any medium, provided you give appropriate credit to the original author(s) and the source, provide a link to the Creative Commons license, and indicate if changes were made.

\section{References}

Anderson, J. E. (1983). Two spliced riddles in the Exeter Book. In Geardagum, 5, 57-75.

Anderson, E. R. (2000). The semantic puzzle of "red gold". English Studies, 81(1), 1-13.

Bitterli, D. (2009). Say what I am called: The Old English riddles of the Exeter Book and the Anglo-Latin riddle tradition. Toronto: University of Toronto Press.

British Library Digitised Manuscripts. Harley MS 585. London: British Library. http://www.bl.uk/ manuscripts/FullDisplay.aspx?ref=Harley_MS_585. Accessed 28 Jan 2016.

British Library Digitised Manuscripts. Royal MS 12 D XVII. London: British Library. http://www.bl.uk/ manuscripts/FullDisplay.aspx?ref=Royal_MS_12_D_XVII. Accessed 28 Jan 2016.

\footnotetext{
14 Niles is also in favour of solving these riddles with the Latin paten and calyx.
} 
Ehwald, R. (Ed.). (1919). Aldhelmi opera omnia. Monumenta Germaniae Historica. Auctores Antiquissimi, 15. Berlin: Weidmann.

Fehr, B. (Ed.). (1914). Die Hirtenbriefe Alfrics in altenglischer und lateinischer Fassung. Bibliothek der Angelsächsischen Prosa, 9. Hamburg: Henri Grand.

Fischer, B., Gryson, R., Gribomont, J., Sparks, H. F. D., Thiele, W., \& Weber, R. (Eds.). (1994). Biblia sacra: iuxta Vulgatam versionem (4th ed.). Stuttgart: Deutsche Bibelgesellschaft.

Foys, M. (forthcoming). The undoing of Exeter Book Riddle 47: "Bookmoth." In G. Caie \& M. D. C. Drout (Eds.). Transitional states: Cultural change, tradition and memory in medieval England. Tempe: Arizona Center for Medieval and Renaissance Studies. Pre-publication draft available online: https://www.academia.edu/15399839/_The_Undoing_of_Exeter_Book_Riddle_47_ Bookmoth_REVISED_pre-publication_draft_. Accessed 24 May 2016.

Healey, A. diP., Haines, D., Holland, McDougall, J. D. \& McDougall, I., with Thompson, P. \& Speirs, N., web interface by Mielke, P. \& Xiang, X. (2007). Dictionary of Old English: A-G online. Toronto: Dictionary of Old English Project. http://tapor.library.utoronto.ca/doe. Accessed 28 Jan 2016.

Hayes, M. (2008). The talking dead: Resounding voices in Old English riddles. Exemplaria, 20(2), 123-142.

Jolly, K. L. (1996). Popular religion in late Saxon England: Elf charms in context. Chapel Hill: University of North Carolina Press.

Kindschi, L. (Ed.). (1955). The Latin-Old English glossaries in Plantin-Moretus MS. 32 and British Museum MS. Additional 32246. Ph.D. diss. Stanford University.

Krapp, G. P., \& Dobbie, E. van K. (Eds.). (1936). The Exeter Book. Anglo-Saxon Poetic Records 3. New York: Columbia University Press.

Muir, B. J. (Ed.). (2000). The Exeter anthology of Old English poetry (2nd ed.). Exeter: University of Exeter Press.

Napier, A. S. (Ed.). (1900). Old English glosses. Anecdota Oxoniensia, Mediaeval and Modern Series 11. Oxford: Clarendon, repr. Hildesheim: G. Olms, 1969.

Nelson, M. (1978). The paradox of silent speech in the Exeter Book riddles. Neophilologus, 62(4), 609-615.

Nelson, M. (1989). Structures of opposition in Old English poems. Amsterdam: Rodopi.

Neville, J. (2013). The Exeter Book Riddles' precarious insights into wooden artefacts. In M. D. J. Bintley \& M. G. Shapland (Eds.), Trees and timber in the Anglo-Saxon world (pp. 122-143). Oxford: Oxford University Press.

Niles, J. D. (2006). Old English enigmatic poems and the play of the texts. Studies in the Early Middle Ages. Turnhout: Brepols.

O'Neill, P. P. (Ed.). (2001). King Alfred's Old English prose translation of the first fifty Psalms. Cambridge, MA: Medieval Academy of America.

Okasha, E. (1993). Old English hring in Riddles 48 and 59. Medium Avum, 62, 61-69.

Okasha, E. (2003). Anglo-Saxon inscribed rings. Leeds Studies in English, 34, 29-45.

Orchard, A. (2016). Performing writing and singing silence in the Anglo-Saxon riddle tradition. In D. Chamberlain \& J. E. Chamberlin (Eds.), Or words to that effect: Orality and the writing of literary history (pp. 73-91). Amsterdam: John Benjamins.

Pinsker, H., \& Ziegler, W. (Eds.). (1985). Die altenglischen Rätsel des Exetersbuch: Text mit deutscher Übersetzung und Kommentar. Heidelberg: Carl Winter.

Salvador-Bello, M. (2015). Isidorean perceptions of order: The Exeter Book riddles and medieval Latin enigmata. Morgantown: West Virginia University Press.

Springer, C. P. E. (Ed.). (2013). Sedulius, the Paschal song and hymns. Atlanta: Society of Biblical Literature.

The Holy Bible Douay-Rheims Version. (1899). Baltimore: John Murphy Company. http://drbo.org. Accessed 24 May 2016.

Williamson, C. (Ed.). (1977). The Old English riddles of the Exeter Book. Chapel Hill: University of North Carolina Press. 